\title{
Determination of the Status of Utilization and Management Scenarios Bonito (Auxis rochei) Caught in theTalaud Waters North Sulawesi
}

\author{
John S. Kekenusa ${ }^{1,}$, , Marline S. Paendong ${ }^{1}$, Winsy Ch. D. Weku ${ }^{1}$, Sendy B. Rondonuwu ${ }^{2}$ \\ ${ }^{1}$ Department of Mathematics, Faculty of Mathematics and Natural Science, Sam Ratulangi University, Manado , Indonesia \\ ${ }^{2}$ Department of Biology, Faculty of Mathematics and Natural Science,Sam Ratulangi University, Manado , Indonesia
}

Email address:

johnskekenusa@yahoo.com (J. S. Kekenusa)

\section{To cite this article:}

John S. Kekenusa, Marline S. Paendong, Winsy Ch. D. Weku, Sendy B. Rondonuwu. Determination of the Status of Utilization and Management Scenarios Bonito (Auxis rochei) Caught in the Talaud Waters North Sulawesi. Science Journal of Applied Mathematics and Statistics. Vol. 3, No. 2, 2015, pp. 39-46. doi: 10.11648/j.sjams.20150302.13

\begin{abstract}
Bonito (Auxis rochei), needs to be managed well because even as a renewable natural resource, but can undergo depletion or extinction. One of the approach in the management of fish resources is by modeling. The analysis was performed aiming to get the best estimate for the surplus production model to determine the maximum sustainable yields (MSY), utilization level, and effort levelof bonito. The data of catch and fishing effort bonito collected from the Marine and Fisheries Service of the Talaud Regency and the North Sulawesi Province. Best Surplus Production Model, which is used to assess the potential of bonito is Schaefer Model. Optimal effort ( $\mathrm{E}_{\mathrm{MSY}}$ ) of 8,489 trips per year, with catches of optimal $\mathrm{C}_{\mathrm{MSY}} 2,453.77$ tons per year. The effort level for 2012 is $193.99 \%$, which shows the inefficiency of effort, the utilization level of $94.86 \%$, showing indicate will occur overfishing.
\end{abstract}

Keywords: Bonito, Surplus Production Model, Maximum Sustainable Yield, Talaud

\section{Introduction}

Bonito (Auxis rochei) classified as pelagic fishery resource is important and one of the non-oil export commodity in North Sulawesi. Bonito production in North Sulawesi (including Talaud waters) in 2011 reached 30,000 tons per year, with a value of about 300 billion rupiahs ${ }^{[1]}$. Research on bonito generally discusses the exploitation to increase production, not much research on the status of utilization (including aspects of sustainability and efficiency) resources.

Catching bonito in waters Talaud has lasted long enough, with high intensity. Data on the level of utilization of the fish resources are very important, as it will determine whether the resource use is less than optimal, optimal, or excessive. Excessive utilization of fish resources would threaten its sustainability. By knowing the level of resource utilization on the bonito, is expected to be done in a planned and sustainable management.

The simplest model of the dynamics of fish populations is Surplus Production Model (SPM), by treating the fish as a single biomass that can not be divided, which is subject to the rules of simple increases and decreases in biomass. This model, commonly used in the assessment of fish stocks using only the data of catch and fishing effort generally available.

This study aims to get the best SPM, as well as knowing how much the result of maximum sustainable yields (MSY), utilization level, and the level of effort of bonito in the Talaud waters.

\section{Surplus Production Model}

The simplest model of the dynamics of fish populations is a surplus production model that treats the fish population as a single biomass that can not be divided, which is subject to the simple rules of the rise and decline. The production model is dependent on the amount of four kinds, namely: biomass population at a given time $t\left(B_{t}\right)$, catches for a certain time $t$ $\left(C_{t}\right)$, fishing effort at a certain time $t\left(E_{t}\right)$, and the natural growth rate constant (r) (Boer and Aziz, 1995).

This model was first developed by Schaefer, who wasinitially the same as the form of logistic growth model.

According to Coppola and Pascoe ${ }^{[2]}$, equation surplus consists of several constants that are affected by natural growth, the ability of fishing gear, and carrying capacity. 
Constants allegedly using models of biological parameter estimators of surplus production equation, namely the model: Equilibrium Schaefer, Schaefer Disequilibrium, Schnute, and Walter - Hilborn. Based on the four models were selected the most appropriate or best fit of the estimation of others.

According to Sparre and Venema ${ }^{[3]}$, formulas surplus production model is valid only if the slope parameter (b) isnegative, which means the addition of fishing effort will lead to a decrease in the catch per fishing effort. If the parameter $b$ positive value, then it can not be done estimating the optimum amount of stock and effort, but it can only be concluded that the addition of fishing effort is still possible to increase the catch.

Prediction of optimum fishing effort $\left(\mathrm{E}_{\mathrm{opt}}\right)$ and the maximum sustainable catch $\left(\mathrm{C}_{\mathrm{MSY}}\right)$ approached the surplus production model. Between the catch per unit of effort (CPUE) and fishing effort can be either linear or exponential relationship ${ }^{[4]}$. Surplus Production Model consists of two models, namely basic model of Schaefer (linear relationship) and the Gompertz model developed by Fox with forms exponential relationship ${ }^{[4]}$.

\subsection{Schaefer Model}

Surplus production models first developed by Schaefer, who was initially the same as the form of logistic growth model. The model is as follows:

$$
\frac{d B_{t}}{d t}=\mathrm{G}\left(B_{t}\right)=\mathrm{r} \mathrm{B}_{\mathrm{t}}\left(1-\frac{B_{t}}{K}\right)
$$

This equation does not include the effect of the catching, so Schaefer wrote back to:

$$
\frac{d B_{t}}{d t}=\mathrm{rB}_{\mathrm{t}}\left(1-\frac{B_{t}}{K}\right)-\mathrm{C}_{\mathrm{t}}
$$

$\mathrm{K}$ is the carrying capacity of the marine environment, and $\mathrm{C}_{\mathrm{t}}$ is the catch that can be written as:

$$
\mathrm{C}_{\mathrm{t}}=\mathrm{q} \mathrm{E} \mathrm{E}_{\mathrm{t}} \mathrm{B}_{\mathrm{t}}
$$

catchability, and Et indicates fishing effort. This equation can be written as:

$$
\frac{C_{t}}{E_{t}}=\mathrm{qB}_{\mathrm{t}}=\mathrm{CPUE}
$$

From the differential equation (2), the optimum catchment can be calculated at the time $\frac{d B_{t}}{d t}=0$, also called settlement at the point of balance (equilibrium), in the formof:

$$
\mathrm{r} \mathrm{B}_{\mathrm{t}}\left(1-\frac{B_{t}}{K}\right)-\mathrm{C}_{\mathrm{t}}=0, \text { or }
$$

$$
\mathrm{C}_{\mathrm{t}}=\mathrm{r} \mathrm{B}_{\mathrm{t}}\left(1-\frac{B_{t}}{K}\right)=\mathrm{q} \mathrm{E}_{\mathrm{t}} \mathrm{B}_{\mathrm{t}}
$$

From equation (3) and (5), find value of $B_{t}$ obtained as follows:

$$
\mathrm{B}_{\mathrm{t}}=\mathrm{K}\left(1-\frac{q E_{t}}{r}\right)
$$

So that equation (5) becomes:

$$
\mathrm{C}_{\mathrm{t}}=\mathrm{qK} \mathrm{E}_{\mathrm{t}}\left(1-\frac{q E_{t}}{r}\right)=\mathrm{qK} \mathrm{E}_{\mathrm{t}}-\frac{q^{2} K}{r} \mathrm{E}_{\mathrm{t}}^{2}
$$

Equation (7) is simplified further by Schaefer becomes:

$$
\begin{aligned}
& \frac{C_{t}}{E_{t}}=\mathrm{a}-\mathrm{bE}_{\mathrm{t}}, \mathrm{or} \\
& \mathrm{C}_{\mathrm{t}}=\mathrm{a} \mathrm{E}_{\mathrm{t}}-\mathrm{b} \mathrm{E} \mathrm{E}_{\mathrm{t}}^{2}
\end{aligned}
$$

while the $\mathrm{a}=\mathrm{q}$ Kand $\mathrm{b}=\frac{q^{2} K}{r}$

This linear relationship is used widely for calculating $\mathrm{C}_{\mathrm{MSY}}$ through the determination of the first derivative of $\mathrm{C}_{t}$ with $E_{t}$ to find optimal solutions, both to catch and fishing effort. The first derivative of $\mathrm{C}_{\mathrm{t}}$ toEtis $: \frac{d C_{t}}{d E_{t}}=\mathrm{a}-2 \mathrm{~b} \mathrm{E}_{\mathrm{t}}$, in order to obtain the alleged $E_{\text {opt }}$ (optimum fishing effort) and $\mathrm{C}_{\mathrm{MSY}}$ (maximum sustainable yields) respectively:

$$
\mathrm{E}_{\mathrm{opt}}=\frac{a}{2 b}=\frac{r}{2 q}
$$

by entering the value of $\mathrm{E}_{\mathrm{opt}}$ in equation (8), will be obtained $\mathrm{C}_{\mathrm{MSY}}$ as follows:

$$
\mathrm{C}_{\mathrm{MSY}}=\mathrm{a} \mathrm{E} \mathrm{E}_{\mathrm{t}}-\mathrm{b} \mathrm{E}_{\mathrm{t}}^{2}=\mathrm{a}\left(\frac{a}{2 b}\right)-\mathrm{b}\left(\frac{a}{2 b}\right)^{2}=\frac{a^{2}}{4 b}
$$

by substituting $\mathrm{a}=\mathrm{qK}$ and $\mathrm{b}=\frac{q^{2} K}{r}$ will be obtained,

$$
\mathrm{C}_{\mathrm{MSY}}=\frac{a^{2}}{4 b}=\frac{q^{2} K^{2}}{4 q^{2} K / r}=\frac{r K}{4}
$$

The valuesof $a$ and $b$ are estimated by the least squares method approach that is commonly used to estimate the coefficient of a simple regression equation. Furthermore, by including the value of $E_{o p t}$ in equation (6) is obtained optimum biomass $\left(\mathrm{B}_{\mathrm{MSY}}\right)$ as follows:

$$
\mathrm{B}_{\mathrm{MSY}}=\mathrm{K}-\frac{K q}{r} E_{o p t}=\mathrm{K}-\frac{K q}{r}\left(\frac{r}{2 q}\right)=\mathrm{K}-\frac{K}{2}=\frac{K}{2}
$$

The values of the parameter $\mathrm{q}, \mathrm{K}$, and $\mathrm{r}$ can be calculated 
using the Fox algorithm, as referenced in Sularso ${ }^{[5]}$, as follows:

$$
\mathrm{q}_{\mathrm{t}}=\ln \left[\left|\left(z U_{t}^{-1}+\frac{1}{b}\right) /\left(z U_{t+1}^{-1}+\frac{1}{b}\right)\right|\right] /(z)
$$

where $\mathrm{z}=-(\mathrm{a} / \mathrm{b}) / \mathrm{E} *, \mathrm{E} *=\left(\mathrm{E}_{\mathrm{t}}+\mathrm{E}_{\mathrm{t}+1}\right) / 2, \mathrm{U}_{\mathrm{t}}=\frac{C_{t}}{E_{t}}$ and the value of $\mathrm{q}$ is the geometric mean of the value of $\mathrm{q}_{\mathrm{t}}$. From the values of $a, b$, and $q$, can then be calculated values of $K$ and $r$.

\subsection{Fox Model}

Model of Fox has several characteristics that are different from the model Schaefer, that it biomass growth following the Gompertz growth model ${ }^{[6]}$. The relation of CPUE with effort (E) follows a negative exponential pattern:

$$
\mathrm{C}_{\mathrm{t}}=\mathrm{E}_{\mathrm{t}} \cdot \exp \left(\mathrm{a}-\mathrm{b} \mathrm{E}_{\mathrm{t}}\right)
$$

Efforts optimum is obtained by equating the first derivative of $\mathrm{Ct}$ to $\mathrm{E}_{\mathrm{t}}$ equal to zero and find :

$$
\mathrm{E}_{\mathrm{opt}}=\frac{1}{b}
$$

Themaximum sustainable yields of catch $\left(\mathrm{C}_{\mathrm{MSY}}\right)$ is obtained by inserting the value of the optimum effort into equation (13), and obtained:

$$
\mathrm{C}_{\mathrm{MSY}}=\frac{1}{b} \mathrm{e}^{\mathrm{a}-1}
$$

\subsection{Schnute Model}

Schnute, suggests another version of the surplus production model is dynamic and deterministic ${ }^{[7]}$. Schnute method is considered as a modification of the model in the form of discrete Schaefer (Roff, 1983, referred by Tinungki) ${ }^{[8]}$.

$$
\begin{aligned}
\ln \left(\frac{U_{t+1}}{U_{t}}\right) & =\mathrm{r}-\frac{r}{q K}\left(\frac{U_{t}+U_{t+1}}{2}\right)-\mathrm{q}\left(\frac{E_{t}+E_{t+1}}{2}\right) \\
& =\mathrm{a}-\mathrm{b}\left(\frac{U_{t}+U_{t+1}}{2}\right)-\mathrm{c}\left(\frac{E_{t}+E_{t+1}}{2}\right)
\end{aligned}
$$

where $\mathrm{a}=\mathrm{r}, \mathrm{b}=\frac{r}{q K}$, and $\mathrm{c}=\mathrm{q}$, is the regression coefficient estimators.

\subsection{Walter-Hilborn Model}

Walter and Hilborn (1976) referred by Tinungki) ${ }^{[8]}$, to develop other types of surplus production model, known as the regression model. Walter -Hilborn Model,using a simple differential equation, by the following equation:

$$
\begin{aligned}
\frac{U_{t+1}}{U_{t}}-1 & =\mathrm{r}-\frac{r}{K q} \mathrm{U}_{\mathrm{t}}-\mathrm{q} \mathrm{E}_{\mathrm{t}} \\
& =\mathrm{a}-\mathrm{b} \mathrm{U}_{\mathrm{t}}-\mathrm{cE}_{\mathrm{t}}
\end{aligned}
$$

where $\mathrm{a}=\mathrm{r}, \mathrm{b}=\frac{r}{K q}$, and $\mathrm{c}=\mathrm{q}$, is the regression coefficient estimators.

\subsection{Clarke Model Yoshimoto Pooley (CYP)}

Estimation of biological parameters for the surplus production model can also be done through estimation techniques proposed by Clarke, Yoshimoto, and Pooley (Fauzi and Anna) ${ }^{[9]}$. The parameters which allegedly is $r, \mathrm{~K}$, and $\mathrm{q}$, the model is expressed as follows:

$$
\ln \left(U_{t+1}\right)=\left(\frac{2 r}{2+r}\right) \ln (q K)+\frac{2-r}{2+r} \ln \left(U_{t}\right)-\frac{q}{2+r}\left(E_{t}+E_{t+1}\right)
$$

where:

$$
a^{\prime}=\frac{2 r}{2+r}, a=a^{\prime} \ln (q K), b=\frac{2-r}{2+r}, c=\frac{q}{2+r}
$$

thus equation (18) can be written in the form:

$$
\begin{aligned}
\ln \left(U_{t+1}\right) & =a^{\prime} \ln (q K)+b \ln \left(U_{t}\right)-c\left(E_{t}+E_{t+1}\right) \\
& =a+b \ln \left(U_{t}\right)-c\left(E_{t}+E_{t+1}\right)
\end{aligned}
$$

\section{Research Methods}

\subsection{Source of Data}

The primary and secondary data of bonito catching is collectedfrom the Talaud waters. Production and fishing effort data collected from the Marine and Fisheries Service of Talaud Regency and North Sulawesi Province during the years 2003-2012.

Data (variables) used for the analysis of the surplus production model is the data of the catch $\left(\mathrm{C}_{t}\right)$ per year and fishing effort $\left(E_{t}\right)$ per year, and CPUE (Catch Per Unit of Effort). The data (variables) used for the analysis of the surplus production model is as follows :

- The catch $\left(\mathrm{C}_{\mathrm{t}}\right)$ : weight of fish landed (tons) in year $\mathrm{t}$

- The Effort of catching $\left(\mathrm{E}_{\mathrm{t}}\right)$ : the number of fishing boat landingresult in a landing (trip) in year $\mathrm{t}$

- $\frac{C_{t}}{E_{t}}$ Catch per Unit of Effort(tons per trip) in year $\mathrm{t}$

\subsection{Methods of Data Analysis}

The models estimator who analyzed and evaluated are : Schaefer, Fox, Schnute, Walter-Hilborn, and ClarkeYoshimoto-Pooley (CYP). Based on the results of statistical evaluation (mark of conformity, the value of $\mathrm{R}^{2}$, the validation value, and significance of the regression coefficient of the model), we get the "best" as estimator. 
From the best ofmodel can be calculated $\mathrm{C}_{\mathrm{MSY}}$ value, optimum fishing effort ( $\left.\mathrm{E}_{\mathrm{MSY}}\right)$, utilization level, and the level of effort of boniti fisher.

\section{Results and Discussion}

Catches of bonito fisheries in the Talaud watersfluctuate from year to year. Data catching in 2003-2012, are presented in Table 1.

Table 1. Total Catch, fishing efforts, and CPUE Tuna Taaud waters of 20032013

\begin{tabular}{llll}
\hline Years & Captured(tons) & Efforts(trip) & CPUE $=\frac{C_{t}}{E_{t}}$ (ton/trip) \\
\hline 2003 & 1625,8 & 2931 & .55469 \\
2004 & 1778,3 & 3444 & .51635 \\
2005 & 1847,3 & 3531 & .52585 \\
2006 & 1941,0 & 2800 & .69321 \\
2007 & 1847,0 & 6825 & .27062 \\
2008 & 1951,8 & 8296 & .23527 \\
2009 & 1958,2 & 8246 & .23747 \\
2010 & 2215,7 & 8496 & .26079 \\
2011 & 2245,8 & 12096 & .18566 \\
2012 & 2327,6 & 16468 & .14341 \\
Mean & 1973,85 & 7313 & 0.36233 \\
\hline
\end{tabular}

Source : Calculated fromthe Marine and Fisheries Service Talaudregrency and North Sulawesi Province data

The results of the regression analysis for the surplus production model is presented in Appendix 1, which is described as follows:

\subsection{Schaefer Model}

From the analysis of regression equation $\mathrm{C}_{\mathrm{t}}=0.636$ $0.00003746 \mathrm{E}_{\mathrm{t}}$, with a coefficient of determination $\left(\mathrm{R}^{2}\right)=$ 0.771 and a significance level of $\mathrm{p}<0.01$. Thus, a production model estimator catches Schaefer model according to the equation (8) is: $C_{t}=0.636 E_{t}-0.00003746 E_{t}^{2}$.

\subsection{Fox Model}

From the results of the regression analysis regression equation:
Ln $\mathrm{C}_{\mathrm{t}}=-0.313-0.000113 \mathrm{E}_{\mathrm{t}}$, with $\mathrm{R}^{2}=0.897(\mathrm{p}<0.01)$. Estimates of catches corresponding to the model Fox equation (13):

$$
C_{t}=E_{t} \cdot e^{\left(-0.313-0.000113 E_{t}\right)}
$$

\subsection{Schnute Model}

Schnute method according to equation (16), obtained regression equation:

$$
\ln \left(\frac{U_{t+1}}{U_{t}}\right)=0.297-0.526\left(\frac{U_{t}+U_{t+1}}{2}\right)-0,0000363\left(\frac{E_{t}+E_{t+1}}{2}\right)
$$

with $\mathrm{R}^{2}=0,035$, and all the regression coefficient was no significant $(\mathrm{p}>0.05)$.

\subsection{Walter Model - Hilborn}

In Walter-Hilborn method using equation (17) derived regression equation

$$
\frac{U_{t+1}}{U_{t}}-1=1.617-2.358 \mathrm{U}_{\mathrm{t}}-0.000128 \mathrm{E}_{\mathrm{t}}
$$

With $\mathrm{R}^{2}=0.391$ and all regression coefficients were not significant $(\mathrm{p}>0.05)$.

\subsection{Clarke Model Yoshimoto Pooley (CYP)}

The regression equation CYP method, according to equation (19):

$$
\ln \left(U_{t+1}\right)=-0.367-0.259 \ln \left(U_{t}\right)-0.00007871\left(E_{t}+E_{t+1}\right)
$$

with $\mathrm{R}^{2}=0.851$, and not all of the regression coefficient are significant.

\section{Discussion}

The results of calculations for validation surplus

\begin{tabular}{|c|c|c|c|c|c|}
\hline & ModelSchaefer & ModelFox & ModelSchnute & ModelWalter-Hilborn & ModelCYP \\
\hline Sign Suitability & Appropriate & Not Appripriate & Appropriate & Appropriate & Not Appripriate \\
\hline $\mathrm{R}^{2}$ Value & 0.771 & 0.897 & 0.035 & 0.391 & 0.851 \\
\hline Validation Value & 0.19664 & 0.15574 & 0.85311 & 0.26546 & 0.77797 \\
\hline SignificanceCoefficient & Signifikan & Signifikan & Not significant & Not significant & Not significant \\
\hline
\end{tabular}
production model of 5 models is presented in Appendix 2, which is summarized in Table 2.

Table 2. Results of the surplus production model validation

From the results of the calculations in Table 2, it appears that the most appropriate is Schaefer model with the $\mathrm{R}^{2}$ value is quite large $\left(\mathrm{R}^{2}=0.771\right)$ and validation (residual value) is relatively small. Schaefer model obtained values of $\mathrm{a}=0.636$ and $b=0.00003746$, with equation (9) and (10) can be calculated optimum value of Effort $\left(\mathrm{E}_{\mathrm{opt}}\right)$ and the maximum sustainable catch $\left(\mathrm{C}_{\mathrm{MSY}}\right)$ as follows:

$$
\mathrm{E}_{\mathrm{opt}}=\frac{a}{2 b}=\frac{0.636}{2(0.00003746)}=8,489.054 \approx 8,489 \text { trips per year. }
$$

$$
\mathrm{C}_{\mathrm{MSY}}=\frac{a^{2}}{4 b}=\frac{0.636^{2}}{4(0.00003746)}=2,453.77 \text { ton per year. }
$$

This means that in order to preserve the bonito fisheries resources technically and biologically, in a year the number of units should not exceed 8,489 trips. To preserve the bonito resources in the waters Talaud Islands, the maximum of fish that can be caught at 2,453.77 tons per year. Furthermore, from the value of $\mathrm{E}_{\mathrm{opt}}$ and $\mathrm{C}_{\mathrm{MSY}}$ can be calculated fishing effort levels and utilization level of bonito for a particular 
year for example in 2012, as follows:

The level of effort in $2012=\frac{E_{2012}}{E_{o p t}} \times 100 \%=\frac{16,468}{8,489} \times 100 \%$

$$
=193.99 \%
$$

The utilization level in 2012 $=\frac{C_{2012}}{C_{M S Y}} \times 100 \%$

$$
=\frac{2327,6}{2453,77} \times 100 \%=94.86 \% \text {. }
$$

From the calculation, it turns out bonito fishing effort at the Talaud waters in 2012, vastly exceeding the maximum sustainable level of effort. This shows that fishing effort is not very efficient. The utilization level for the year 2012, although not beyond the optimum level, however, be a sign of overfishing (catch-over). This study describes the use of some statistical criteria in selecting the best surplus production model. By applying some statistical criteria in selecting a surplus production model, will obtain better results. Researchers in the field of fisheries get guidelines for setting selection criteria for surplus production models, as well as avoiding the direct application of one model in analyzing the surplus production model in a waters.

\section{Conclusions and Recommendations}

\section{Appendix}

\section{Appendix 1. Regression analysis of Surplus Production Model of bonito data in Talaud Waters}

\section{Model Schaefer}

Model Summary

\begin{tabular}{lllll}
\hline Model & R & R Square & Adjusted R Square & Std. Error of the Estimate \\
\hline 1 & $.878^{\mathrm{a}}$ & .771 & .743 & .09661061 \\
\hline
\end{tabular}

a. Predictors: (Constant), Et

Coefficients $^{a}$

\begin{tabular}{llllll}
\hline \multirow{2}{*}{ Model } & & \multicolumn{2}{l}{ Unstandardized Coefficients } & \multicolumn{2}{l}{ Standardized Coefficients } \\
\cline { 3 - 5 } & & B & Std. Error & Beta & Sig. \\
\hline \multirow{2}{*}{1} & (Constant) & .636 & .061 & .000 & 10.440 \\
& Et & $-3.746 \mathrm{E}-005$ & .000 & -.878 & -5.195 \\
\hline
\end{tabular}

a. Dependent Variable: Ut

ANOVA ${ }^{a}$

\begin{tabular}{llllll}
\hline Model & & Sum of Squares & Df & Mean Square & F \\
\hline \multirow{2}{*}{1} & Regression & .252 & 1 & .252 & 26.985 \\
& Residual & .075 & 8 & .009 & \\
& Total & .327 & 9 & & \\
\hline
\end{tabular}

a. Dependent Variable: Ut

b. Predictors: (Constant), Et 


\section{Model Fox}

Model Summary

\begin{tabular}{lllll}
\hline Model & R & R Square & Adjusted R Square & Std. Error of the Estimate \\
\hline 1 & $.947^{\mathrm{a}}$ & .897 & .885 & .18150109 \\
\hline
\end{tabular}

a. Predictors: (Constant), Et

ANOVA ${ }^{a}$

\begin{tabular}{lllllll}
\hline Model & Sum of Squares & df & Mean Square & F & Sig. \\
\hline Regression & 2.306 & 1 & 2.306 & 70.009 & $.000^{\mathrm{b}}$ \\
Residual & .264 & 8 & .033 & & \\
Total & 2.570 & 9 & & & \\
\hline
\end{tabular}

a. Dependent Variable: Ln Ut

b. Predictors: (Constant), Et

Coefficients $^{a}$

\begin{tabular}{|c|c|c|c|c|c|c|}
\hline \multirow{2}{*}{ Model } & & \multicolumn{2}{|c|}{ Unstandardized Coefficients } & \multirow{2}{*}{$\begin{array}{l}\text { Standardized Coefficients } \\
\text { Beta }\end{array}$} & \multirow{2}{*}{$\mathbf{t}$} & \multirow{2}{*}{ Sig. } \\
\hline & & B & Std. Error & & & \\
\hline \multirow{2}{*}{1} & (Constant) & -.313 & .115 & & -2.734 & .026 \\
\hline & Et & .000 & .000 & -.947 & -8.367 & .000 \\
\hline
\end{tabular}

a. Dependent Variable: Ln Ut

\section{Model Schnute}

Model Summary

\begin{tabular}{lllll}
\hline Model & R & R Square & Adjusted R Square & Std. Error of the Estimate \\
1 & $.188^{\mathrm{a}}$ & .035 & -.286 & .39571729 \\
\hline
\end{tabular}

a. Predictors: (Constant), $(E t+E t+1) / 2,(U t+U t+1) / 2$

ANOVA ${ }^{a}$

\begin{tabular}{llllll}
\hline Model & & Sum of Squares & df & Mean Square & F \\
\hline \multirow{2}{*}{1} & Regression & .034 & 2 & .017 & .110 \\
& Residual & .940 & 6 & .157 & \\
& Total & .974 & 8 & & \\
\hline
\end{tabular}

a. Dependent Variable: $\mathrm{Ln}(\mathrm{Ut}+1 / \mathrm{Ut}$

b. Predictors: (Constant), $(\mathrm{Et}+\mathrm{Et}+1) / 2,(\mathrm{Ut}+\mathrm{Ut}+1) / 2$

Coefficients $^{a}$

\begin{tabular}{llllll}
\hline \multirow{2}{*}{ Model } & & \multicolumn{2}{l}{ Unstandardized Coefficients } & \multicolumn{2}{l}{ Standardized Coefficients } \\
\cline { 3 - 5 } & & B & Std. Error & Beta & t \\
\hline \multirow{2}{*}{1} & $($ Constant $)$ & .297 & 1.402 & & .212 \\
& $(\mathrm{Ut}+\mathrm{Ut}+1) / 2$ & -.526 & 2.096 & -.255 & -.251 \\
& $(\mathrm{Et}+\mathrm{Et}+1) / 2$ & $-3.632 \mathrm{E}-005$ & .000 & -.393 & .810 \\
\hline
\end{tabular}

a. Dependent Variable: $\operatorname{Ln}(\mathrm{Ut}+1 / \mathrm{Ut}$

\section{Model Walter - Hilborn}

Model Summary

\begin{tabular}{lllll}
\hline Model & R & R Square & Adjusted R Square & Std. Error of the Estimate \\
\hline 1 & $.625^{\text {a }}$ & .391 & .188 & .23701636 \\
\hline
\end{tabular}

a. Predictors: (Constant), Et, Ut 
ANOVA

\begin{tabular}{llllll}
\hline Model & & Sum of Squares & df & Mean Square & F \\
\hline \multirow{3}{*}{1} & Regression & .216 & 2 & .108 & 1.926 \\
& Residual & .337 & 6 & .056 & \\
& Total & .553 & 8 & & \\
\hline
\end{tabular}

a. Dependent Variable: $(U t+1+U t)-1$

b. Predictors: (Constant), Et, Ut

Coefficients $^{a}$

\begin{tabular}{llllll}
\hline \multirow{2}{*}{ Model } & & \multicolumn{2}{l}{ Unstandardized Coefficients } & \multicolumn{2}{l}{ Standardized Coefficients } \\
\cline { 3 - 5 } & & B & Std. Error & Beta & \multicolumn{1}{c}{ Sig. } \\
\hline \multirow{2}{*}{1} & (Constant) & 1.617 & .882 & & .116 \\
& Ut & -2.358 & 1.206 & -1.657 & -1.954 \\
& Et & .000 & .000 & -1.592 & -1.878 \\
\hline
\end{tabular}

a. Dependent Variable: $(U t+1+U t)-1$

\section{Model CYP}

Model Summary

\begin{tabular}{lllll}
\hline Model & R & R Square & Adjusted R Square & Std. Error of the Estimate \\
\hline 1 & $.923^{\mathrm{a}}$ & .851 & .802 & .23507945 \\
\hline
\end{tabular}

a. Predictors: (Constant), $(\mathrm{Et}+\mathrm{Et}+1), \mathrm{Ln} \mathrm{Ut}$

ANOVA $^{a}$

\begin{tabular}{llllll}
\hline Model & & Sum of Squares & df & Mean Square & F \\
\hline \multirow{3}{*}{1} & Regression & 1.899 & 2 & .949 & 17.179 \\
& Residual & .332 & 6 & .055 & \\
& Total & 2.230 & 8 & & \\
\hline
\end{tabular}

a. Dependent Variable: $\mathrm{Ln}(\mathrm{Ut}+1)$

b. Predictors: (Constant), $(\mathrm{Et}+\mathrm{Et}+1), \mathrm{Ln} \mathrm{Ut}$

Coefficients $^{a}$

\begin{tabular}{|c|c|c|c|c|c|c|}
\hline \multirow{2}{*}{ Model } & & \multicolumn{2}{|c|}{ Unstandardized Coefficients } & \multirow{2}{*}{$\begin{array}{l}\text { Standardized Coefficients } \\
\text { Beta }\end{array}$} & \multirow{2}{*}{$\mathbf{t}$} & \multirow{2}{*}{ Sig. } \\
\hline & & $\mathbf{B}$ & Std. Error & & & \\
\hline \multirow{3}{*}{1} & (Constant) & -.367 & .198 & & -1.850 & .114 \\
\hline & Ln Ut & -.259 & .376 & -.236 & -.687 & .517 \\
\hline & $(E t+E t+1)$ & $-7.871 \mathrm{E}-005$ & .000 & -1.126 & -3.277 & .017 \\
\hline
\end{tabular}

a. Dependent Variable: Ln (Ut+1)

Appendix 2. Validation of Surplus Production Models of Bonito Data

\begin{tabular}{|c|c|c|c|c|c|c|c|}
\hline \multirow[t]{2}{*}{ Years } & \multirow[t]{2}{*}{$\begin{array}{l}C_{t} \\
\text { (tons) }\end{array}$} & \multirow[t]{2}{*}{$\begin{array}{l}\mathbf{E}_{\mathrm{t}} \\
\text { (trips) }\end{array}$} & \multicolumn{5}{|c|}{ Validation: $\operatorname{Abs}\left(\frac{C_{t}-\hat{C}_{t}}{C_{t}}\right)$} \\
\hline & & & Schaefer & Fox & Schnute & Walter- Hilborn & CYP \\
\hline 2003 & $1,625.8$ & 2931 & 0.05136 & 0.05338 & 0.34666 & 0.06996 & 0.21907 \\
\hline 2004 & $1,778.3$ & 3444 & 0.01813 & 0.04036 & 0.36669 & 0.05484 & 0.28556 \\
\hline 2005 & $1,847.3$ & 3513 & 0.04078 & 0.06501 & 0.38719 & 0.07904 & 0.25916 \\
\hline 2006 & $1,941.0$ & 2800 & 0.23384 & 0.23124 & 0.46418 & 0.24554 & 0.01996 \\
\hline 2007 & $1,847.0$ & 6825 & 0.49399 & 0.46457 & 0.60188 & 0.48373 & 0.37726 \\
\hline 2008 & $1,951.8$ & 8296 & 0.38238 & 0.21722 & 0.96691 & 0.04549 & 1.32234 \\
\hline 2009 & $1,958.2$ & 8246 & 0.37744 & 0.21277 & 0.98175 & 0.04291 & 1.30589 \\
\hline 2010 & $2,215.7$ & 8496 & 0.21836 & 0.07356 & 0.91724 & 0.18055 & 1.07649 \\
\hline 2011 & $2,245.8$ & 12096 & 0.01498 & 0.00397 & 0.45415 & 0.90183 & 1.44751 \\
\hline 2012 & $2,327.6$ & 16468 & 0.13519 & 0.19531 & 3.04449 & 0.55067 & 1.46648 \\
\hline Mean & $1,973.85$ & 7,313 & 0.19664 & 0.15574 & 0.85311 & 0.26546 & 0.77797 \\
\hline
\end{tabular}


1. Model Schaefer:

$$
\hat{C}_{t}=0,636 E_{t}-0,00003746 E_{t}^{2}
$$

2. Model Fox:

$$
\hat{C}_{t}=E_{t} \cdot e^{\left(-0,313-0,000113 E_{t}\right)}
$$

3. Model Schnute:

$$
\begin{gathered}
\hat{Y}=a-b X_{1}-c X_{2}=0,297-0,526 X_{1}-0,000363 X_{2} \\
\mathrm{r}=\mathrm{a}=0,297 \mathrm{q}=\mathrm{c}=0,0000363 \mathrm{~b}=\frac{r}{K q}=0,526 \\
\mathrm{~K}=\frac{r}{b q}=\frac{0,297}{(0,526)(0,0000363)}=15554,79 \\
\hat{C}_{t}=K q E_{t}-\frac{K q^{2}}{r} E_{t}^{2}=0,56464 \mathrm{E}_{\mathrm{t}}-0,000069 \mathrm{E}_{\mathrm{t}}^{2}
\end{gathered}
$$

4. Model Walter - Hilborn:

$$
\begin{gathered}
\hat{Y}=a-b X_{1}-c X_{2}=1,617-2,358 X_{1}-0,000128 X_{2} \\
\mathrm{r}=\mathrm{a}=1,617 \mathrm{q}=\mathrm{c}=0,000128 \mathrm{~b}=\frac{r}{K q}=2,358 \\
\mathrm{~K}=\frac{r}{b q}=\frac{1,617}{(2,358)(0,000128)}=5357,43 \\
\hat{C}_{t}=K q E_{t}-\frac{K q^{2}}{r} E_{t}{ }^{2}=0,67504 \mathrm{E}_{\mathrm{t}}-0,0000543 \mathrm{E}_{\mathrm{t}}^{2}
\end{gathered}
$$

5. Model CYP:

$$
\begin{aligned}
\hat{Y}=a+ & b X_{1}-c X_{2}=-0,367-0,259 X_{1}-0,00007871 X_{2} \\
r & =\frac{2(1-b)}{1+b}=\frac{2(1+0,259)}{1-0,259}=3,39811 \\
q & =-c(2-r)=-0,00007871(2-3,39811)=0,00011 \\
Q & =\frac{a(2+r)}{2 r}=\frac{-0,367(2+3,39811)}{2(3,39811)}=-0,29150
\end{aligned}
$$

$$
\begin{gathered}
K=\frac{e^{Q}}{q}=\frac{e^{-0,29150}}{0,00011}=6792,20 \\
\hat{C}_{t}=K q E_{t}-\frac{K q^{2}}{r} E_{t}^{2}=0,74714 \mathrm{E}_{\mathrm{t}}-0,0000242 \mathrm{E}_{\mathrm{t}}^{2}
\end{gathered}
$$

\section{References}

[1] [DKP]Dinas Kelautan dan Perikanan Provinsi Sulawesi Utara.2012. Statistik Perikanan Tangkap ProvinsiSulawesi Utara Tahun 2011.

[2] Coppola G., and S. Pascoe.1996.A Surplus Production Model with a non-linear Catch-Effort Relationship.(Research Paper 105) Center for the Economics and Managemant of Aquatic Resources University of Portsmouth.

[3] Sparre, P. and S.C. Venema.1999.Introduksi Pengkajian Stok Ikan Tropis.Buku 1 Manual. (Terjemahan J. Widodo. I.G.S. Merta, S. Nurhakim, dan M. Badrudin). Pusat Penelitian dan Pengembangan Perikanan, Badan Penelitian dan Pengembangan Pertanian (Kerjasama dengan Organisasi Pangan dan Pertanian Perserikatan Bangsa-bangsa). Jakarta. 438 hal.

[4] Gulland, J.A.1983.Fishing andStock of Fish at Iceland.Mui. 'Agric. Fish Food, Invest. (Ser.2) 23(4): 52 - 70.

[5] Sularso, A. 2005. Alternatif Pengelolaan Perikanan Udang di Laut Arafura.Disertasi (Tidak Dipublikasikan).Sekolah Pascasarjana Institut Pertanian Bogor.Bogor. 130 hal.

[6] Fox, W.W. 1970. An Exponential Surplus Yield Model for Optimazing Exploited Fish Population. Trans. Am. Fish Soc. 99(1):80-88.

[7] Schnute, J. 1977. Improved Estimates from the Schaefer Production Models: Theoretical Considerations: J. Fish. Res. Board Can., 34:583-663.

[8] Tinungki, G. M. 2005. Evaluasi Model Produksi Surplus dalam Menduga Hasil Tangkapan Maksimum Lestari untuk Menunjang Pengelolaan Perikanan Lemuru Di Selat Bali. Disertasi (Tidak Dipublikasikan).Sekolah Pascasarjana Institut Pertanian Bogor. Bogor. 207 hal.

[9] Fauzi, A., dan S. Anna.2005.Pemodelan Sumberdaya Perikanan dan Kelautan untuk Analisis Kebijakan. PT. Gramedia Pustaka Utama, Jakarta. 